San Jose State University

SJSU ScholarWorks

Master's Theses

Master's Theses and Graduate Research

Summer 2013

\title{
Response of Waterbirds to Salt Pond Enhancements and Island Creation in the San Francisco Bay
}

Stacy M. Moskal

San Jose State University

Follow this and additional works at: https://scholarworks.sjsu.edu/etd_theses

\section{Recommended Citation}

Moskal, Stacy M., "Response of Waterbirds to Salt Pond Enhancements and Island Creation in the San Francisco Bay" (2013). Master's Theses. 4355.

DOI: https://doi.org/10.31979/etd.z3rc-6vhd

https://scholarworks.sjsu.edu/etd_theses/4355

This Thesis is brought to you for free and open access by the Master's Theses and Graduate Research at SJSU ScholarWorks. It has been accepted for inclusion in Master's Theses by an authorized administrator of SJSU ScholarWorks. For more information, please contact scholarworks@sjsu.edu. 


\title{
RESPONSE OF WATERBIRDS TO SALT POND ENHANCEMENTS AND ISLAND
} CREATION IN THE SAN FRANCISCO BAY

\author{
A Thesis \\ Presented to \\ The Faculty of the Department of Biological Sciences \\ San José State University
}

In Partial Fulfillment

of the Requirements for the Degree

Master of Sciences

by

Stacy M. Moskal

August 2013 
(C) 2013

Stacy M. Moskal

ALL RIGHTS RESERVED 
The Designated Thesis Committee Approves the Thesis Titled

RESPONSE OF WATERBIRDS TO SALT POND ENHANCEMENTS AND ISLAND CREATION IN THE SAN FRANCISCO BAY

by

Stacy M. Moskal

APPROVED FOR THE DEPARTMENT OF BIOLOGICAL SCIENES

SAN JOSÉ STATE UNIVERSITY

August 2013

Dr. Scott A. Shaffer Department of Biological Sciences, SJSU

Dr. John Y. Takekawa U. S. Geological Survey - San Francisco Bay

Estuary

Dr. Lynne Trulio Department of Environmental Studies, SJSU 


\title{
ABSTRACT
}

RESPONSE OF WATERBIRDS TO SALT POND ENHANCEMENTS AND ISLAND CREATION IN THE SAN FRANCISCO BAY

\author{
by Stacy M. Moskal
}

Historically, San Francisco Bay supported the largest salt pond complex on the Pacific coast of North America, and these areas have been used by large numbers of migrating and wintering waterbirds for more than a century. In 2003 , salt ponds in the South San Francisco Bay were purchased with a goal of restoring 50$90 \%$ of the 6100 ha of former salt ponds to replace lost tidal marsh habitats. However, a major challenge for the restoration project has been maintaining the abundance of non-breeding waterbirds in a smaller footprint of managed ponds. Thus, in 2009-2010, Pond SF2 was enhanced with 30 islands of two different shapes and water control structures that provided muted tidal flows with shallow water depths predicted to benefit waterbirds. To assess how non-breeding waterbirds responded to these enhancements, a spatial grid $(50 \mathrm{~m} \times 50 \mathrm{~m})$ was used to survey SF2 weekly from October to May 2010-2012, and examine waterbird use. Of the 262,932 non-breeding waterbirds observed, only $12-15 \%$ used the islands depending on tide. Island size, shape, or both predicted the presence or relative abundance of some foraging guilds, whereas island slope, perimeter, and distance to mudflat did not improve the model's predictions of relative guild abundances. Results indicated that waterbirds were attracted to areas with shallow water depths; however, the constructed islands were not used by a large number of waterbirds. 


\section{ACKNOWLEDGMENTS}

This study was supported by CSU COAST, the South Bay Salt Pond Restoration Project, The Resources Legacy Fund, J. Ackerman and the Davis USGS, and USGS Western Ecological Research Center. Permission to access refuge lands was provided by Don Edwards San Francisco Bay National Wildlife Refuge Complex (C. Strong and E. Mruz). Field assistance was provided by B. Wensky, K. Barry, V. Bui, J. Liechty, L. Hollander, K. Lovett, S. Piotter, C. Potter and K. Hirsch. Statistical guidance was provided by Dr. Luis Bonachea. GIS support was provided by Lacy M. Smith. 


\section{TABLE OF CONTENTS}

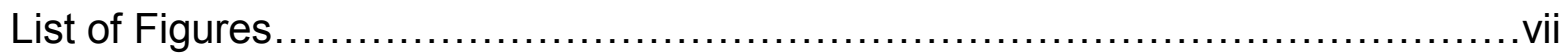

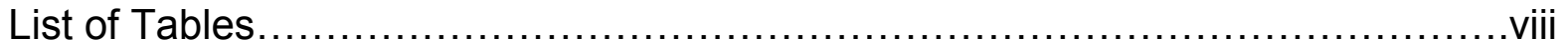

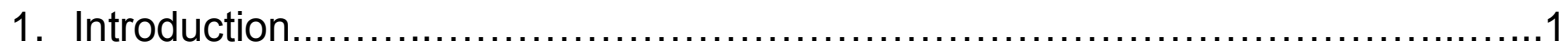

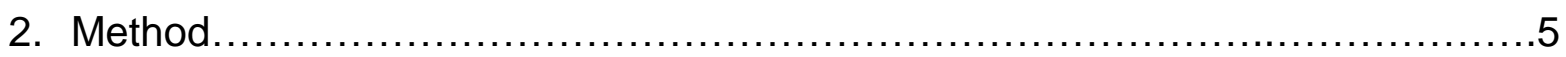

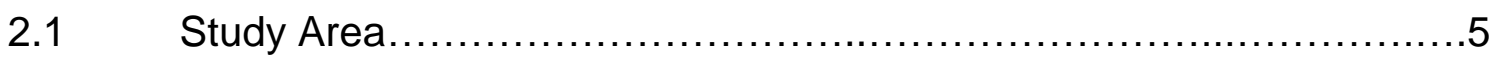

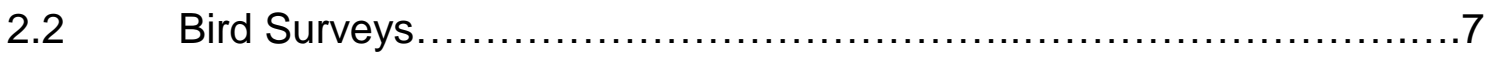

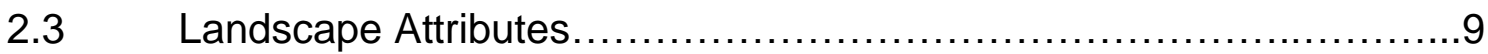

$2.4 \quad$ Data Analysis........................................................... 10

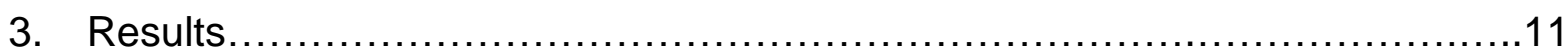

3.1 Overall Bird Abundances...............................................

3.2 Total Bird Abundances on Islands ....................................12

3.3 Relative Bird Abundances on Islands................................16

3.4 Presence or Absence of Bird Guilds on Islands........................16

3.5 Relative Guild Abundances on Islands..............................19

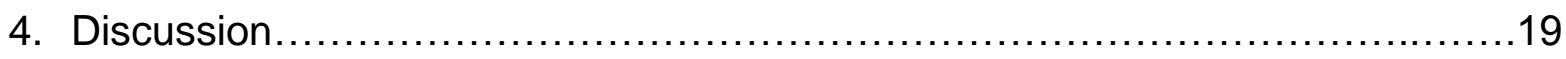

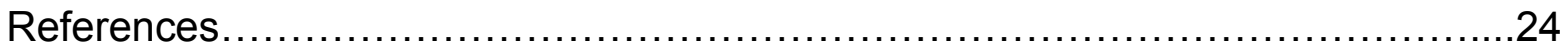




\section{LIST OF FIGURES}

Figure 1. The San Francisco Estuary ......................................6

Figure 2. Temporal Trends in Waterbird Abundances...........................11

Figure 3. Relative Abundances of All Bird Guilds by Year and Season............14

Figure 4. Total Bird Abundance on Islands..................................15

Figure 5. Mean Bird Abundances on Islands...............................17 


\section{LIST OF TABLES}

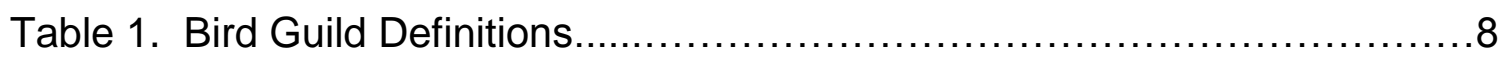

Table 2. Species List with Abundances and Frequencies........................13

Table 3. MANOVA Results....................................................... 18

Table 4. Binary Logistic Regression Results.................................18 


\section{Introduction}

Estuaries provide ecosystem services such as flood and coastal protection, water purification, and carbon sequestration as well as the direct benefits of wildlife diversity (including endangered species), transportation, and recreational areas (Barbier, 2011; Junk et al., 2013; Okamoto \& Wong, 2011). The San Francisco Bay and Delta comprise the largest estuary on the west coast of the Americas and home to the federally and state-endangered California clapper rail (Rallus longirostris obsoletus), least tern (Sterna antillarum browni), salt marsh harvest mouse (Reithrodontomys raviventris), soft bird's-beak (Cordylanthus mollis ssp. mollis), the threatened California black rail (Laterallus jamaicensis coturniculus), and red-legged frog (Rana draytonii), the California species of special concern: salt marsh common yellow-throat (Geothlypis trichas sinuosa) and salt marsh song sparrows (the Suisun song sparrow, Melospiza melodia maxillaris; Samuel's song sparrow, M. m. samuelis; and the Alameda song sparrow, M.m. pusillula) (Viana, 2006). The San Francisco Bay Estuary (hereafter SFB Estuary) is located along the central coast of California, surrounded by a large urban center with a population of $>7.5$ million (San Francisco Estuary Partnership, 2011). This region is heavily affected by human activities such as water pollution from agricultural, industrial, and urban runoff, introduction of non-native species, legacy heavy metals such as mercury from earlier mining operations, and commercial and residential development.

The present SFB Estuary is made up of wetlands and tidal marshes, deep channels, shallow waters, and tidal flats, although only $9 \%$ of the historical tidal 
marshes remain (Goals Project, 1999). Over the past 250 years, these tidal marshes have been filled to support the expanding human population, diked and drained to allow for more livestock grazing and agricultural production, especially in the North and Central Bays, and used for salt production in the South and North Bays (Goals Project, 1999). In 2000, over 8,800 ha of historical wetlands were being used for salt production (Kay, 2002). Although the anthropogenic effects to this estuary are great, it still supports tremendous biodiversity including more than 1.7 million waterbirds representing at least 250 species (H.T. Harvey \& Associates, 2005; Okamoto \& Wong, 2011). The estuary has been designated as a Western Hemisphere Shorebird Reserve Network (WHSRN) Site of Hemispheric Importance in recognition of the large number of migrating and wintering shorebirds that it supports. In 2013, the bay-delta was also designated a RAMSAR site (named after Ramsar, Iran, where the first convention was held; Ramsar, 1971), a wetland of international importance.

A number of restoration plans have been created to promote a more sustainable estuarine system with improved ecosystem health. The San Francisco Bay Estuary is currently undergoing tidal marsh restoration. The largest tidal marsh restoration in the estuary is the South Bay Salt Pond Restoration Project (the Restoration Project) plan. This Restoration Project will convert at least $50 \%$ of 12,140 ha of former salt ponds in the South Bay back into a tidal marsh system (EDAW et al., 2007; Goals Project, 1999). This area had been in active salt production since the 1940s. In 2003, the U.S. Fish and Wildlife Service (USFWS) 
and the California Department of Fish and Wildlife bought 7,250 hectares of salt ponds in the San Francisco Bay from the Cargill Corporation with the intent to use the land for restoration of its natural resource values (Kay, 2002).

While restoring tidal salt marsh is a primary goal of the Restoration Project, this must be balanced with maintaining habitat for waterbirds in managed ponds. Salt ponds are considered a valuable resource to migrating, wintering, and nesting waterbirds (Takekawa et al., 2001). Globally, salt ponds provide critical roosting and breeding habitat as well as foraging areas at high tide for a number of waterbird guilds including small, medium, and large shorebirds (Ackerman et al., 2009; Sripanomyom et al., 2011). Indeed, some foraging guilds (small and medium shorebirds, diving ducks, eared grebes, and phalaropes) prefer the salt pond habitat, and conversion of the ponds to tidal marsh may negatively affect these guilds (Athearn et al., 2012; Goals Project, 1999; Goals Project, 2000).

As the salt ponds are converted and tidal marsh restored, a primary challenge is to maintain the abundance of migratory and wintering birds in a much smaller footprint of managed ponds (EDAW et al., 2007). A number of pond enhancements have been introduced to determine what features are most attractive to breeding and non-breeding waterbirds (EDAW et al., 2007). One enhancement proposal has been to add a number of islands, levees, or floating platforms to provide more roosting areas. To test the effects of shape and density of islands, experimental islands were created in salt pond SF2. The Restoration Project planned several studies to evaluate the use of islands in SF2 by waterbirds. This information is 
critical to satisfying the needs of resource managers and future planners because these enhancements are costly to implement, require considerable time to construct, and may create additional problems to operate or manage. Thus, studies and ongoing monitoring of island habitat use by waterbirds are needed.

Numerous studies have examined non-breeding waterbird use of salt ponds (Dias, 2009; Masero \& Perez-Hurtado, 2001; Takekawa et al., 2001; Warnock \& Takekawa, 1995; Warnock et al., 2002; Velasquez, 1992), as well as roost site characteristics (Conkin et al., 2008; Dias et al., 2006; Goss-Custard et al., 2006; Peters \& Otis, 2007; Rogers, 2003; Rosa et al., 2006) and general use of islands by breeding birds (Burger \& Lesser, 1978; Burgess \& Hirons, 1992; Eason et al., 2012; Erwin et al., 2003; Giroux, 1981; Maggiulli \& Dugger, 2011; Shaffer et al., 2006). However, little information exists about bird use of islands in salt ponds by nonbreeding birds. Parnell et al. (1986) provided an account of species present on dredge islands in North Carolina, and Burton et al. (1996) studied the bird use of one newly-created island in a United Kingdom harbor. These studies found that up to 70 different species roosted on islands made from the dredged material byproduct from channel construction; the newly created island was the preferred roost location, and roost use was largely dependent upon tide height and wind speed. However, researchers found island use decreased over time, possibly due to increased disturbances such as helicopters, boats, raptors, and rats (Burton et al.,1996).

At pond SF2, 30 islands of two different shapes were created as nesting and roosting habitat for breeding, wintering, and migrating waterbirds. To provide 
information to Project managers on the use of the SF2 islands by non-breeding birds, I examined the spatial and temporal differences in habitat use of waterbirds at SF2. I wanted to determine if: (1) birds used newly formed islands, (2) total bird abundance on islands varied over time given tidal fluctuations and seasonal trends, (3) relative guild abundances varied by island, (4) shape or size of island could be used to predict the presence of specific guilds, or (5) relative guild abundances could be predicted by island shape, size, perimeter, slope, and distance to mudflat. The null hypotheses I developed and tested were: (1) total bird abundances on islands do not vary at high or low tide, (2) relative guild abundances on islands do not vary at high or low tide, (3) the presence or absence of a guild on an island is not predicted by island size or shape at high or low tide, (4) the relative guild abundance on an island is not predicted by island shape, size, perimeter, slope, and distance to mudflat.

\section{Method}

\section{$2.1 \quad$ Study Area}

Former Salt Pond SF2 $\left(37^{\circ} 29^{\prime} \mathrm{N} 122^{\circ} 07^{\prime} \mathrm{W}\right)$ is a 57 ha impoundment located in the south San Francisco Bay, CA and is part of the larger Restoration Project (Figure 1). The pond is part of an urban setting in the municipalities of East Palo Alto and Menlo Park to the west, U. S. Highway 84 borders the pond to the north. In 2009-2010, as part the Restoration Project, the USFWS enhanced SF2 by placing 30 waterbird islands ranging in size from $1439 \mathrm{~m}^{2}$ to $2363 \mathrm{~m}^{2}$. There were two experimental units in the pond: Unit 1 (23 ha) which contained eight islands and 
was closest to the Bay, and Unit 2 (34 ha) which contained 22 islands and was farther from the Bay. Screw-gate water control structures were placed along the Bay-front levee and weir boxes were installed in internal levees to allow for water level manipulations. All of the islands had a north facing slope that provided protection

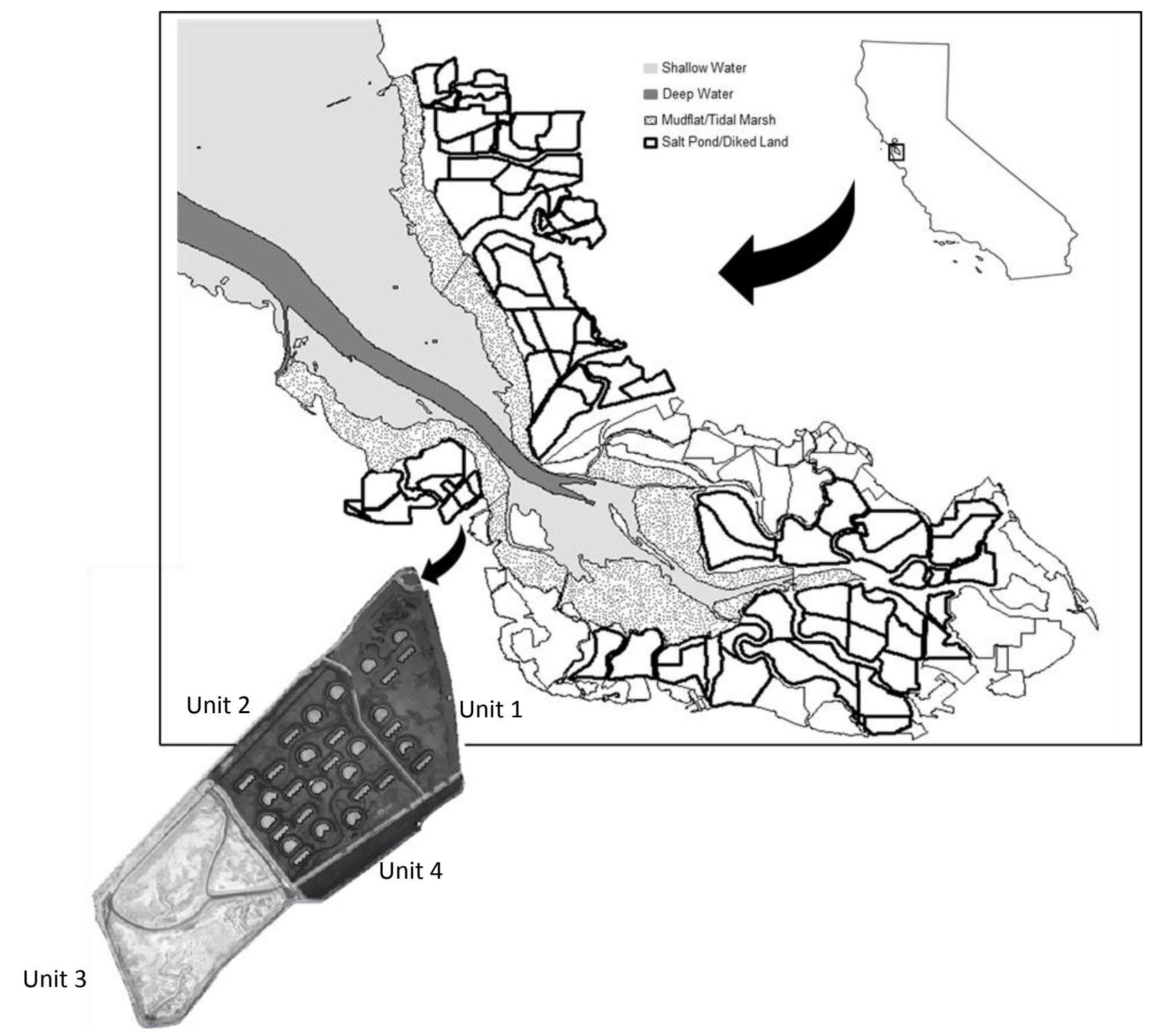

Figure 1. The South San Francisco Bay Estuary and the ponds in the South Bay Salt Pond Restoration Project (SFEI, Eco-Atlas, 2004) and aerial view of the field site, Pond SF2 (USGS, 2010) with units in the pond labeled. 
from northwest winds, which was the typical wind direction for the Bay region. Half of the islands were crescent-shaped: falcate-curved shapes with a low island-edgeto-area ratio; whereas the others were linear: long and rectangular with a saw-tooth south edge providing a high island-edge-to-area ratio. Over time, island area (size) and shape varied because tidal flow and wind influenced sediment deposition, but each island maintained its original, underlying shape.

\subsection{Bird Surveys}

I used instantaneous scan sampling (Altmann, 1974) of all birds present on the pond weekly from October 1 through May 12 during 2010-2011 and 2011-2012 with $10 \times 40$ binoculars and a $60 \times$ spotting scope. I used an aerial photograph of the pond that was superimposed by $50 \times 50 \mathrm{~m}$ Universal Transverse Mercator (UTM) grids to spatially record birds in specific grids. This survey period and regularity allowed me to monitor habitat use of southward fall migrants, overwintering birds, and northward spring migrants. I considered a survey complete when a diurnal high tide and low tide count were conducted within a 24-hour period. High tide counts were conducted within 1.5 hours of the diurnal high tide (ranging from 5.1-10.3 ft.) and provided a count of the maximum number of birds using the pond as their low tide foraging and roosting sites are flooded, whereas low tide counts were conducted within 1.5 hours of the diurnal low tide (ranging from $-1.8-3.6 \mathrm{ft}$.$) and provided the$ minimum number (Dias, 2009). Counts were conducted in all environmental conditions except for high winds (+40 kph) or heavy rain. 
To survey the entire pond, I drove to three fixed vantage points: two were located on observational platforms installed by the USFWS at a height of 4-6 m above pond bottom and one was atop a vehicle (3-5 $\mathrm{m}$ above the pond bottom). These viewing platforms provided a comprehensive view of the whole study area. I counted all birds observed on the pond by ones, tens, or hundreds depending on the size of the group. I then assigned the birds to a grid (e.g., A5B4), and to one of these six microhabitat types: man-made structure, open water, island, shallows of the island, levee, or exposed pond bottom. All birds were identified to species with the exception of long-billed and short-billed dowitchers (dowitchers) and greater and lesser scaup (scaup), because they were difficult to separate accurately in the field. For most analyses, species were grouped into foraging guilds based on commonly accepted categories (Helmers, 1992; Table 1).

Table 1. Bird guilds defined by foraging habitat and size (Helmers, 1992; Sibley, 2003). An example bird is given for each guild.

\begin{tabular}{llcl}
\hline Guild & Foraging Description & Bird Length $(\mathrm{cm})$ & Example \\
\hline Dabbler & At or near surface of water & $35-61$ & Mallard \\
Diver & water column or benthos & $33-64$ & Bufflehead \\
Small Shorebird (all Calidris) & aquatic gleaner/prober & up to 23 & Western Sandpiper \\
Medium Shorebird & aquatic gleaner/prober & $23-38$ & Dowitcher \\
Large Shorebird & typically aquatic prober & $38-59$ & Long-billed Curlew \\
Yellowlegs & aquatic gleaner & $25-38$ & Willet \\
Turnstone & terrestrial or aquatic gleaner/prober & $18-30$ & Ruddy Turnstone \\
Tern (all Sterna) & water column & $33-54$ & Forster's Tern \\
Recurve & aquatic gleaner/sweeper & $35-46$ & Black-necked Stilt \\
Raptor & typically terrestrial, carnivorous & $25-50$ & Red-tailed Hawk \\
Plover & terrestrial/aquatic gleaner & $15-30$ & Black-bellied Plover \\
Piscivore & water column & $55-155$ & American White Pelican \\
Heron & stalking in water column & $60-120$ & Great Egret \\
Gull & glean, capture, or scavenge, omnivorous & $33-65$ & California Gull \\
Grebe & water column or benthos & $33-65$ & Eared Grebe \\
Goose & terrestrial or aquatic gleaner & $60-120$ & Canada Goose \\
Passerine & glean, capture, or scavenge, omnivorous & $40-60$ & American Crow \\
\hline
\end{tabular}




\subsection{Landscape Attributes}

Island elevation was estimated by collecting data on the surface of all 30 islands; data points were collected $5 \mathrm{~m}$ apart on 22 islands and $1 \mathrm{~m}$ apart on the other eight islands. Ground elevation surveys were conducted with a Leica VIVA Real Time Kinematic Global Positioning System (RTK GPS) rover unit capable of collecting survey-grade elevation and $x$ and $y$ position data (UTM) from the Leica Smartnet system $( \pm 3 \mathrm{~cm} x, y$, and $z$ accuracy; Leica Geosystems Inc., Norcross, GA). The unit averaged $\pm 2.5 \mathrm{~cm}$ vertical error at a reference benchmark (X 552 1956 Mare Island),-which is within the stated error of the unit. All data were collected and reported in meters with horizontal datum UTM NAD83 zone 10 and vertical datum NAVD88.

The Spatial Analyst tool (ArcGIS 9.3.1, ESRI, Redlands, CA) was used to create digital elevation models. I used the Inverse-Distance Weighting method to interpolate the elevation point data within the boundary of each island outline. The island digital elevation models were used with Spatial Analyst tools to calculate the mean slope and aspect of each island.

The centerlines of pond levees were digitized using 2005 and 2009 National Agricultural Imagery Program (NAIP) imagery (1-m resolution, UTM NAD83 zone 10). The islands, mudflat edge, highway edge, and power line were digitized from a 2010 aerial image with 11-cm resolution. The "Near" tool function in the Analysis 
Tools toolbox (ArcGIS 9.3.1) was used to calculate distances from the center point of each island to mudflat edge.

\subsection{Data Analysis}

Because I focused on non-breeding birds, any nesting species observed on the pond were noted but not included in analyses. The American Avocet (Recurvirostra americana) was the only species observed nesting on or within the pond boundary, the first day of nesting was March 20 for both years. To examine temporal trends, I classified surveys into three celestial seasons: the fall (1 October 21 December), the winter (22 December - 19 March), and the spring (20 March - 30 May) for each year. Microhabitats were grouped into two categories: pond (manmade structures, open water, exposed pond bottom, and levees), and island (island and island shallows).

To determine if there was a trend in total abundances by island, I used a Kruskal-Wallis non-parametric test, because of the lack of normality, followed by Tukey's post hoc tests for island pairwise comparisons. To examine whether relative use by guilds on islands varied, I conducted a multivariate analysis of variance (MANOVA) using relative abundances as the response variables. A binary logistic regression was used to examine whether shape and size of island had an effect on guild presence or absence. Finally, linear mixed models were used to explore how relative abundances of guilds changed in relation to some island characteristics. The model was fitted with fixed coefficients (fixed effects) of island shape and random coefficients (random effects) of mean island slope, distance from 
center of island to edge of mudflat, area, and island perimeter. All statistical analyses were conducted with SPSS, v.20.0 (IBM Corporation, New York) applying a significance value of $p<0.05$. Data are presented as means $\pm 95 \%$ confidence intervals unless otherwise noted.

\section{Results}

\subsection{Overall bird abundances in pond and on islands by tide}

I conducted 112 counts during the two field seasons (60 the first year, 52 the second year), and I observed an estimated 262,932 birds using the pond and its associated islands. The majority ( $86 \%)$ of birds were observed using the pond whereas the remainder (14\%) utilized the islands. Most of the birds were counted on high tide counts $(N=56)$ with $31,016(15 \%)$ observed on islands and 180,648 $(85 \%)$ in the water or on the pond bottom or levee. Low tide counts were lower at $6,094(12 \%)$ on islands and $45,174(88 \%)$ in other habitats (Figure 2$)$. Thus, $80.5 \%$ of all birds observed were counted in the pond during the high tide. Lower total bird
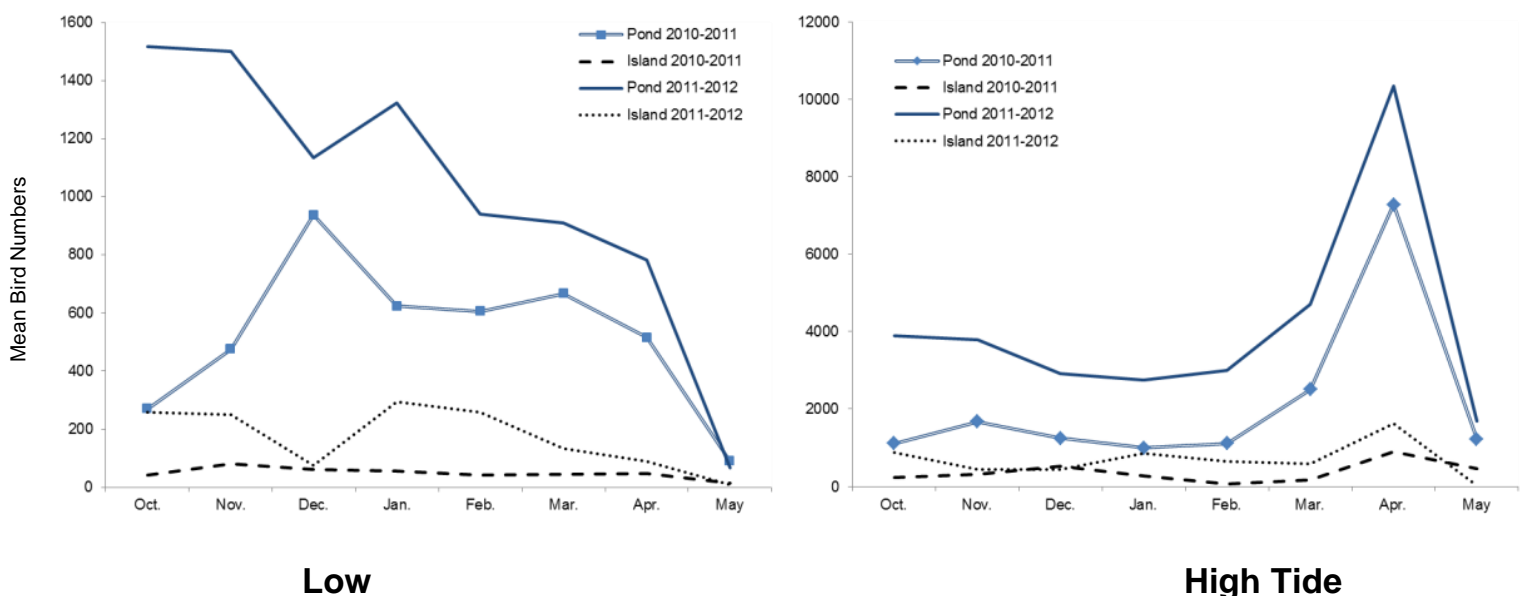

Low

High Tide

Figure 2. Temporal trend in waterbird abundances for low and high tides across years. The data are separated into whether birds were observed using the pond or on islands. Note bird abundances were scaled differently to clearly show the trends. 
abundance was observed in the first field season; the abundance of birds surveyed in the second season was $73.7 \%$ greater.

I identified a total of 67 bird species over the course of two years, listed in Table 2. Western sandpipers (Calidris mauri) were the most abundant species and comprised 89,097 individuals. There were two waterbird species that were only observed once throughout the survey period: blue-winged teal (Anas discors), and ruddy turnstone (Arenaria interpres). The birds present in the greatest numbers of counts were not necessarily the most abundant. For example, snowy egrets (Egretta thula) were present at every count, but accounted for only $0.90 \%$ of the total birds observed, whereas the western sandpiper was seen at $84 \%$ of the counts and was $34 \%$ of total number of birds detected.

Winter season had lower bird counts than the other two seasons, with the highest relative abundance of small sandpipers in the spring (Figure 3). During high tide, the islands had the highest abundances during the spring, whereas during low tide islands were used more heavily during the fall and the winter (Figure 4).

\subsection{Total bird abundances on islands by tide and season}

In general, island use was widespread but not evenly distributed among all 30 islands and was affected by both season and tide. For example, total abundance differed significantly between islands $(\mathrm{H}(29)=93.5, p<0.001)$. This trend continued when high and low tide abundances were evaluated separately: high tide $(H(29)=$ 
Table 2. Complete species list sorted by abundance. There were 30 surveys completed in year 1 and 26 surveys in year 2 . Frequency (\%) was calculated by using presence/absence during each survey.

\begin{tabular}{|c|c|c|c|c|c|c|c|c|c|c|c|}
\hline \multirow{2}{*}{ Common Name } & \multirow{2}{*}{ Scientific Name } & \multirow{2}{*}{ Guild } & \multicolumn{3}{|c|}{ Abundance } & \multicolumn{3}{|c|}{ Relative Percentage } & \multicolumn{3}{|c|}{ Frequency in Percent } \\
\hline & & & $\mathrm{Y} 1$ & Y2 & Combined & $\mathrm{Y} 1$ & Y2 & Combined & $\mathrm{Y} 1$ & Y2 & Combined \\
\hline Snowy Egret & Egretta thula & Heron & 1189 & 1178 & 2367 & 1.24 & 0.71 & 0.90 & 100 & 100 & 100 \\
\hline Double-crested & Phalacrocorax auritus & Piscivore & 1096 & 2068 & 3164 & 1.14 & 1.24 & 1.20 & 96.67 & 100 & 98.21 \\
\hline Great Egret & Ardea alba & Heron & 181 & 726 & 907 & 0.19 & 0.44 & 0.34 & 96.67 & 100 & 98.21 \\
\hline Least Sandpiper & Calidris minutilla & Sm. Sho rebird & 3784 & 4969 & 8753 & 3.94 & 2.98 & 3.33 & 96.67 & 92.31 & 94.64 \\
\hline Mallard & Anas platyrhynchos & Dabbler & 409 & 1126 & 1535 & 0.43 & 0.67 & 0.58 & 93.33 & 96.15 & 94.64 \\
\hline Northern Shoveler & Anas clypeata & Dabbler & 13056 & 5852 & 18908 & 13.59 & 3.51 & 7.19 & 93.33 & 92.31 & 92.86 \\
\hline American Wigeon & Anas americana & Dabbler & 2542 & 2780 & 5322 & 2.65 & 1.67 & 2.02 & 86.67 & 96.15 & 91.07 \\
\hline Ruddy Duck & Oxyura jamaicensis & Diver & 4569 & 9899 & 14468 & 4.76 & 5.93 & 5.50 & 83.33 & 92.31 & 87.50 \\
\hline Dunlin & Calidris alpina & Sm. Sho rebird & 4210 & 13115 & 17325 & 4.38 & 7.86 & 6.59 & 93.33 & 76.92 & 85.71 \\
\hline Western Sandpiper & Calidris mauri & Sm. Sho rebird & 43156 & 45941 & 89097 & 44.92 & 27.53 & 33.89 & 93.33 & 73.08 & 83.93 \\
\hline Willet & Catoptrophorus & Yellowlegs & 4105 & 8225 & 12330 & 4.27 & 4.93 & 4.69 & 70.00 & 96.15 & 82.14 \\
\hline Ring-billed Gull & Larus delawarensis & Gull & 496 & 1190 & 1686 & 0.52 & 0.71 & 0.64 & 66.67 & 100 & 82.14 \\
\hline American Coot & Fulica americana & Dabbler & 808 & 1147 & 1955 & 0.84 & 0.69 & 0.74 & 73.33 & 84.62 & 78.57 \\
\hline Greater Yellowlegs & Tringa melanoleuca & Yellowlegs & 59 & 142 & 201 & 0.06 & 0.09 & 0.08 & 60.00 & 100.00 & 78.57 \\
\hline Northern Pintail & Anas acuta & Dabbler & 1444 & 9516 & 10960 & 1.50 & 5.70 & 4.17 & 60.00 & 92.31 & 75.00 \\
\hline Bufflehead & Bucephala albeola & Diver & 1805 & 1712 & 3517 & 1.88 & 1.03 & 1.34 & 70.00 & 80.77 & 75.00 \\
\hline California Gull & Larus californicus & Gull & 107 & 1657 & 1764 & 0.11 & 0.99 & 0.67 & 60.00 & 92.31 & 75.00 \\
\hline Gadwall & Anas strepera & Dabbler & 135 & 793 & 928 & 0.14 & 0.48 & 0.35 & 56.67 & 92.31 & 73.21 \\
\hline Great Blue Heron & Heron Ardea & Heron & 39 & 121 & 160 & 0.04 & 0.07 & 0.06 & 60.00 & 88.46 & 73.21 \\
\hline M arbled Go dwit & Limosafedoa & Lg. Sho rebird & 1500 & 17125 & 18625 & 1.56 & 10.26 & 7.08 & 53.33 & 92.31 & 71.43 \\
\hline Dowitcher (Long-billed & Limnodromus spp & Med. Sho rebird & 2168 & 7312 & 9480 & 2.26 & 4.38 & 3.61 & 50.00 & 92.31 & 69.64 \\
\hline Herring Gull & Larus argentatus & Gull & 43 & 251 & 294 & 0.04 & 0.15 & 0.11 & 53.33 & 88.46 & 69.64 \\
\hline American Avocet & Recurvirostra americana & Recurve & 4639 & 13935 & 18574 & 4.83 & 8.35 & 7.06 & 63.33 & 73.08 & 67.86 \\
\hline Long-billed Curlew & Numenius americanus & Lg. Sho rebird & 564 & 1254 & 1818 & 0.59 & 0.75 & 0.69 & 43.33 & 92.31 & 66.07 \\
\hline Common Goldeneye & Bucephala clangula & Diver & 336 & 174 & 510 & 0.35 & 0.10 & 0.19 & 70.00 & 53.85 & 62.50 \\
\hline Forster's Tern & Sterna forsteri & Tern & 543 & 474 & 1017 & 0.57 & 0.28 & 0.39 & 60.00 & 61.54 & 60.71 \\
\hline Eared Grebe & Podiceps nigricollis & Grebe & 102 & 36 & 138 & 0.11 & 0.02 & 0.05 & 66.67 & 53.85 & 60.71 \\
\hline Black-necked Stilt & Himantopus mexicanus & Recurve & 185 & 179 & 364 & 0.19 & 0.11 & 0.14 & 43.33 & 73.08 & 57.14 \\
\hline Black-bellied Plover & Pluvialis squatarola & Plover & 201 & 1016 & 1217 & 0.21 & 0.61 & 0.46 & 36.67 & 76.92 & 55.36 \\
\hline Canvasback & Aythya valisineria & Diver & 83 & 3486 & 3569 & 0.09 & 2.09 & 1.36 & 50.00 & 57.69 & 53.57 \\
\hline Western Gull & Larus occidentalis & Gull & 30 & 136 & 166 & 0.03 & 0.08 & 0.06 & 30.00 & 76.92 & 51.79 \\
\hline Semipalmated Plover & Charadrius semipalmatus & Plover & 1809 & 1350 & 3159 & 1.88 & 0.81 & 1.20 & 40.00 & 57.69 & 48.21 \\
\hline Scaup (Greater and & Aythya spp & Diver & 179 & 1099 & 1278 & 0.19 & 0.66 & 0.49 & 43.33 & 53.85 & 48.21 \\
\hline Whimbrel & Numenius phaeopus & Lg. Sho rebird & 126 & 74 & 200 & 0.13 & 0.04 & 0.08 & 30.00 & 69.23 & 48.21 \\
\hline Red-breasted & Mergus serrator & Piscivore & 5 & 128 & 133 & $<0.01$ & 0.08 & 0.05 & 13.33 & 73.08 & 41.07 \\
\hline American Green- & Anas crecca & Dabbler & 20 & 5725 & 5745 & 0.02 & 3.43 & 2.18 & 13.33 & 69.23 & 39.29 \\
\hline Canada Goose & Branta canadensis & Goose & 86 & 90 & 176 & 0.09 & 0.05 & 0.07 & 36.67 & 38.46 & 37.50 \\
\hline Horned Grebe & Podiceps auritus & Grebe & 30 & 15 & 45 & 0.03 & 0.01 & 0.02 & 40.00 & 26.92 & 33.93 \\
\hline Pied-billed Grebe & Podilymbus podiceps & Grebe & 3 & 38 & 41 & $<0.01$ & 0.02 & 0.02 & 10.00 & 61.54 & 33.93 \\
\hline Brown Pelican & Pelecanus occidentalis & Piscivore & 56 & 135 & 191 & 0.06 & 0.08 & 0.07 & 33.33 & 30.77 & 32.14 \\
\hline Lesser Yellowlegs & Tringa flavipes & Yellowlegs & 15 & 21 & 36 & 0.02 & 0.01 & 0.01 & 26.67 & 38.46 & 32.14 \\
\hline Killdeer & Charadrius vociferus & Plover & 18 & 9 & 27 & 0.02 & 0.01 & 0.01 & 26.67 & 23.08 & 25.00 \\
\hline American White & Pelican pelecanus & Piscivore & 14 & 537 & 551 & 0.01 & 0.32 & 0.21 & 10.00 & 30.77 & 19.64 \\
\hline Western Grebe & Aechmophorus occidentalis & Grebe & 4 & 17 & 21 & $<0.01$ & 0.01 & 0.01 & 6.67 & 30.77 & 17.86 \\
\hline Western Snowy Plover & Charadrius alexandrinus & Plover & 64 & 1 & 65 & 0.07 & $<0.01$ & 0.02 & 26.67 & 3.85 & 16.07 \\
\hline Peregrine Falcon & Falco peregrinus & Raptor & 9 & 3 & 12 & $<0.01$ & $<0.01$ & $<0.01$ & 16.67 & 7.69 & 12.50 \\
\hline Caspian Tern & Sterna caspia & Tern & 0 & 32 & 32 & 0.00 & 0.02 & 0.01 & 0 & 23.08 & 10.71 \\
\hline Eurasian Wigeon & Anas penelope & Dabbler & 3 & 3 & 6 & $<0.01$ & $<0.01$ & $<0.01$ & 10.00 & 11.54 & 10.71 \\
\hline Common Merganser & Mergus merganser & Piscivore & 0 & 21 & 21 & 0.00 & 0.01 & 0.01 & 0 & 19.23 & 8.93 \\
\hline Common Raven & Corvus corax & Passerine & 5 & 5 & 10 & $<0.01$ & $<0.01$ & $<0.01$ & 10.00 & 7.69 & 8.93 \\
\hline Elegant Tern & Sterna elegans & Tern & 0 & 7 & 7 & 0.00 & $<0.01$ & $<0.01$ & 0 & 19.23 & 8.93 \\
\hline Northern Harrier & Circus cyaneus & Raptor & 6 & 1 & 7 & $<0.01$ & $<0.01$ & $<0.01$ & 13.33 & 3.85 & 8.93 \\
\hline $\begin{array}{l}\text { Bonaparte's Gull } \\
\text { Black-crowned Night- }\end{array}$ & Larus philadelphia & Gull & 27 & 0 & 27 & 0.03 & $<0.01$ & 0.01 & 10.00 & 0 & 5.36 \\
\hline Heron & Nycticorax nycticorax & Heron & 2 & 1 & 3 & $<0.01$ & $<0.01$ & $<0.01$ & 6.67 & 3.85 & 5.36 \\
\hline Spotted Sandpiper & Actitis macularia & Turnstone & 4 & 0 & 4 & $<0.01$ & $<0.01$ & $<0.01$ & 6.67 & 0 & 3.57 \\
\hline Clark's Grebe & Aechmophorus clarkii & Grebe & 0 & 2 & 2 & $<0.01$ & $<0.01$ & $<0.01$ & 0 & 7.69 & 3.57 \\
\hline Merlin & Falco columbarius & Raptor & 2 & 0 & 2 & $<0.01$ & $<0.01$ & $<0.01$ & 3.33 & 0 & 1.79 \\
\hline Glaucous-winged Gull & Larus glaucescens & Gull & 2 & 0 & 2 & $<0.01$ & $<0.01$ & $<0.01$ & 3.33 & 0 & 1.79 \\
\hline Barrow's Goldeneye & Bucephala islandica & Diver & 0 & 2 & 2 & $<0.01$ & $<0.01$ & $<0.01$ & 0 & 3.85 & 1.79 \\
\hline Red Knot & Calidris canutus & Med. Sho rebird & 2 & 0 & 2 & $<0.01$ & $<0.01$ & $<0.01$ & 3.33 & 0 & 1.79 \\
\hline Red-tailed Hawk & Buteo jamaicensis & Raptor & 1 & 0 & 1 & $<0.01$ & $<0.01$ & $<0.01$ & 3.33 & 0 & 1.79 \\
\hline Thayer's Gull & Larus thayeri & Gull & 1 & 0 & 1 & $<0.01$ & $<0.01$ & $<0.01$ & 3.33 & 0 & 1.79 \\
\hline White-tailed Kite & Elanus leucurus & Raptor & 0 & 1 & 1 & $<0.01$ & $<0.01$ & $<0.01$ & 0.00 & 3.85 & 1.79 \\
\hline Blue-winged Teal & Anas discors & Dabbler & 1 & 0 & 1 & $<0.01$ & $<0.01$ & $<0.01$ & 3.33 & 0 & 1.79 \\
\hline Mew Gull & Larus canus & Gull & 1 & 0 & 1 & $<0.01$ & $<0.01$ & $<0.01$ & 3.33 & 0 & 1.79 \\
\hline Ruddy Turnstone & Arenaria interpres & Turnstone & 0 & 1 & 1 & $<0.01$ & $<0.01$ & $<0.01$ & 0 & 3.85 & 1.79 \\
\hline
\end{tabular}



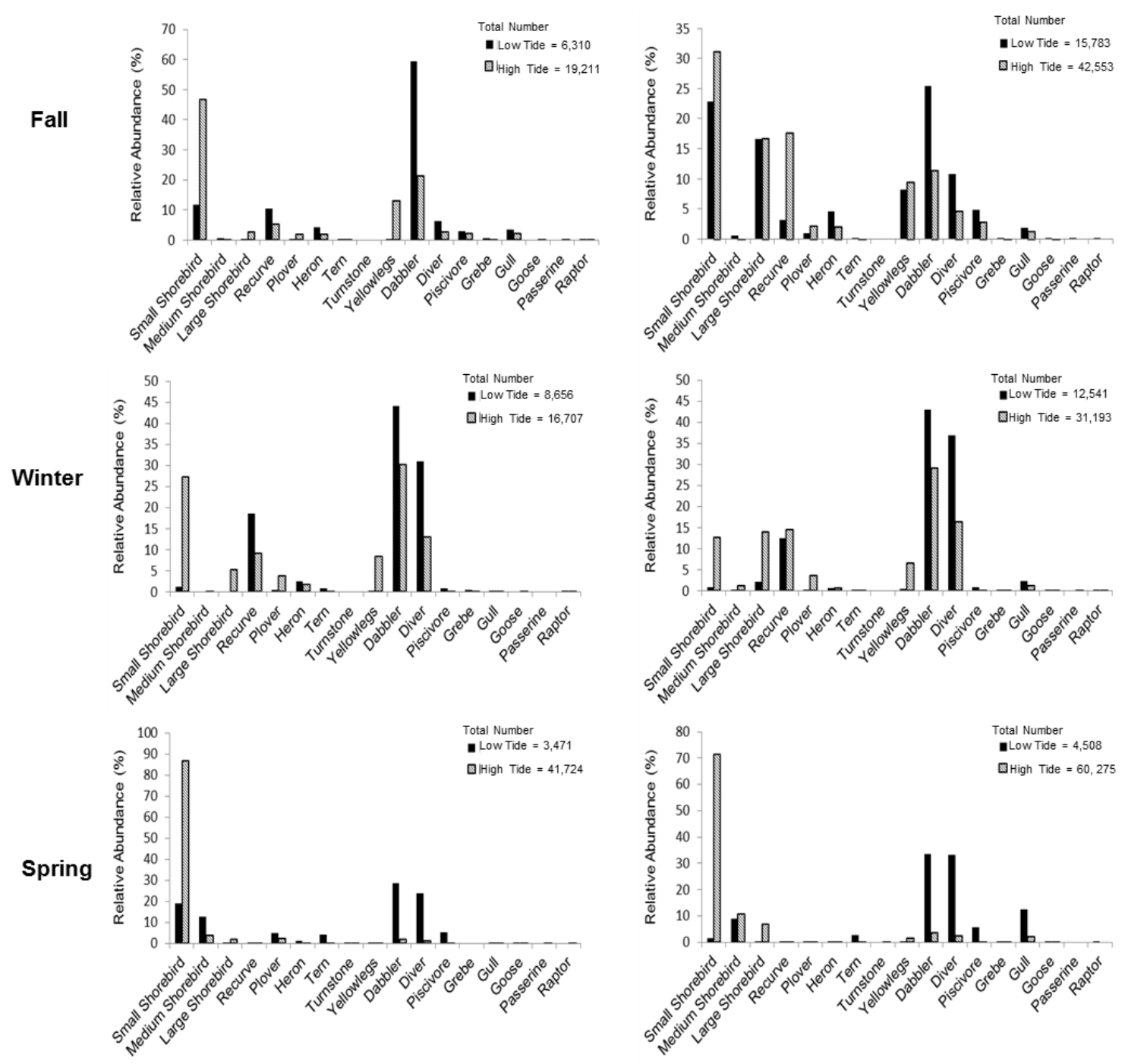

Figure 3. Relative abundance of all bird guilds by year and season. Each frame includes total number of birds by tide. Note that relative abundance has different scales, based on the percentage of the dominant guild. 


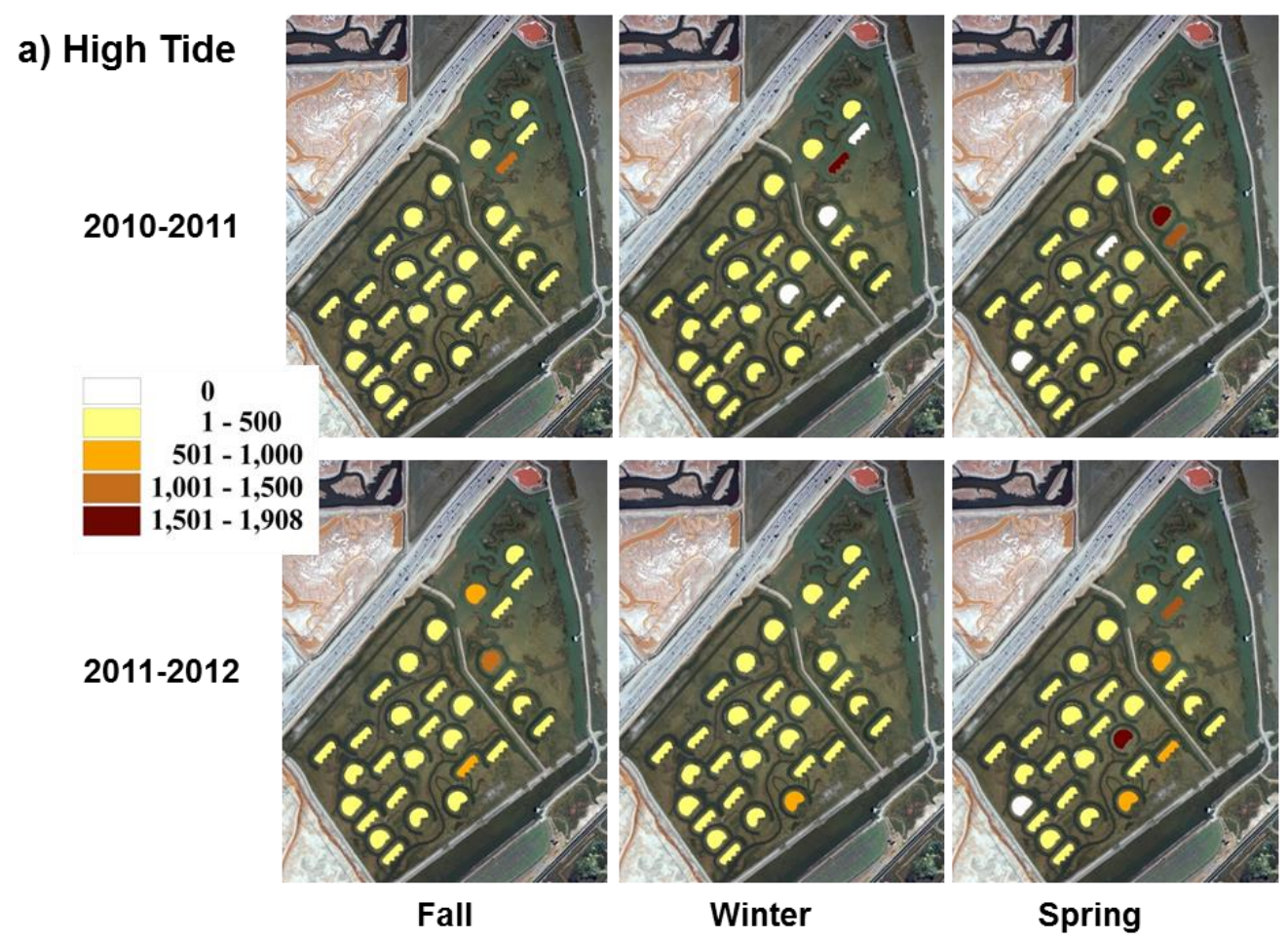

b) Low Tide

2010-2011
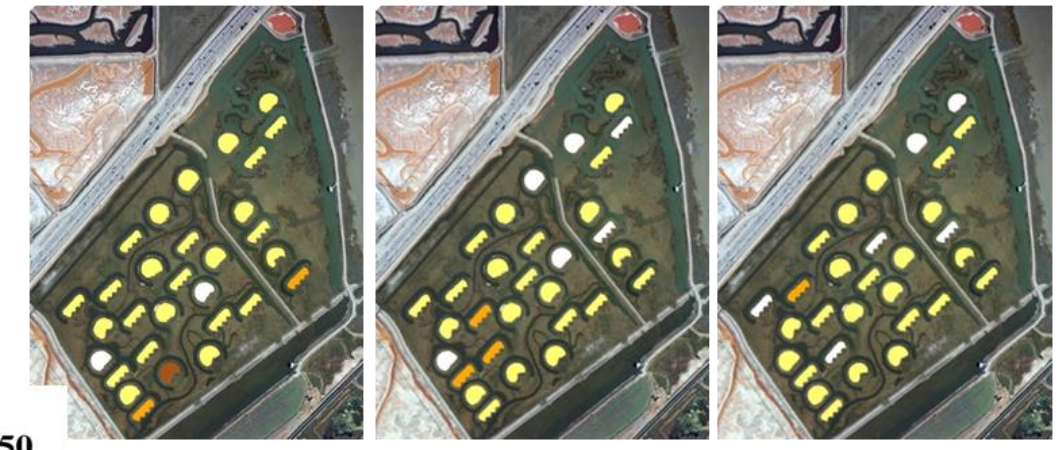

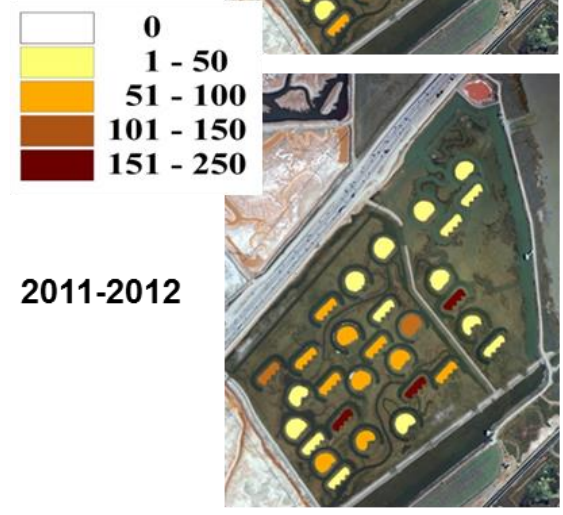

Fall

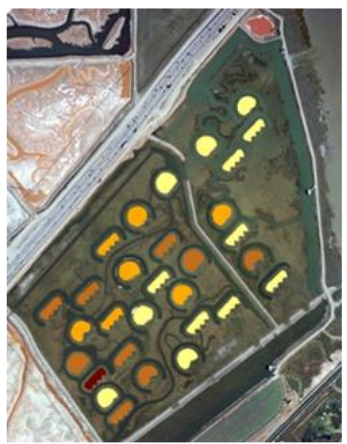

Winter

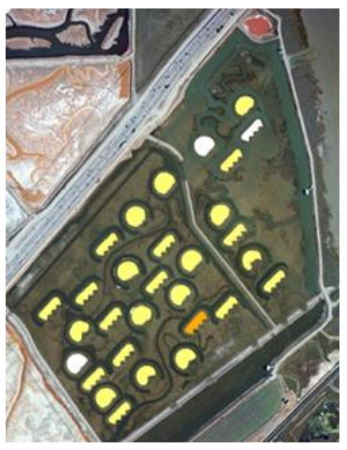

Spring

Figure 4. Total bird abundance observed on islands by season for the two survey years. Panel a is high tide data and Panel $b$ is low tide data. 
55.7, $p=0.002)$ and low tide $(\mathrm{H}(29)=68.6, p<0.001)$. Islands 24 and 25 had a total abundance significantly different from nearly all other islands at high tide. Total abundance for island 24 was the highest and differed significantly from all other islands except 14,17 , and 25 , respectively (Figure 5). At low tide, all islands had abundances that were not statistically different.

\subsection{Relative bird abundances by island and tide}

The relative abundance of some guilds varied across islands, as indicated in Table 3. At low tide, medium and large shorebirds as well as dabblers, piscivores, and gull abundances were significantly different among islands. At high tide, differences among islands were seen with small and large shorebirds, recurves, plovers, yellowlegs, dabblers, piscivores, and gulls.

\subsection{Presence/absence of guilds predicted by island shape and size}

The binary logistic regression model revealed that the presence or absence of some guilds could be predicted by island shape or size. At low tide, the presence of dabblers $(p=0.004)$ was most commonly associated with smaller islands, whereas gulls were associated with larger islands $(p=0.030)$. Shape was not a significant predictor of guild presence at low tide, as detailed in Table 4. At high tide, a model including shape significantly improved prediction of the greater presence of small shorebirds on crescent-shaped islands $(p=0.031)$ and herons on linear islands $(p=0.022)$. The inclusion of island size significantly improved prediction of the greater presence of large shorebirds on larger islands $(p=0.036)$ and of dabblers on smaller islands $(p=0.030)$. The presence of gulls was better predicted by a model 
including both size and shape ( $p=0.007)$, as gulls more often used linear $(p=0.010)$, large $(p=0.007)$ islands.

a)

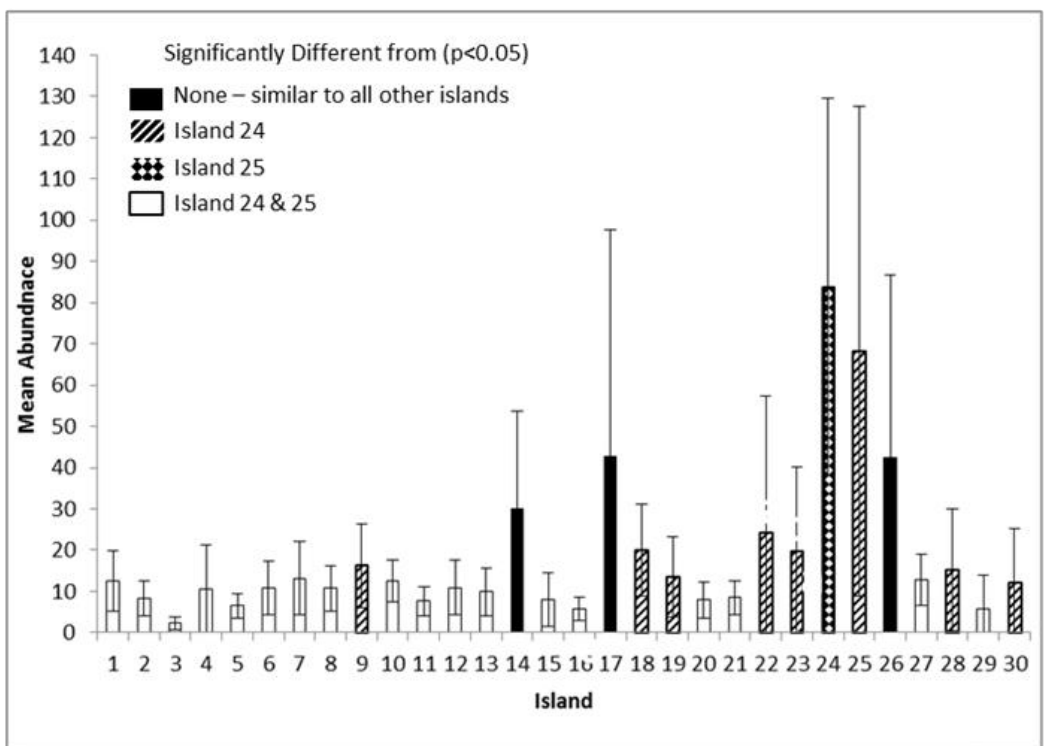

b)

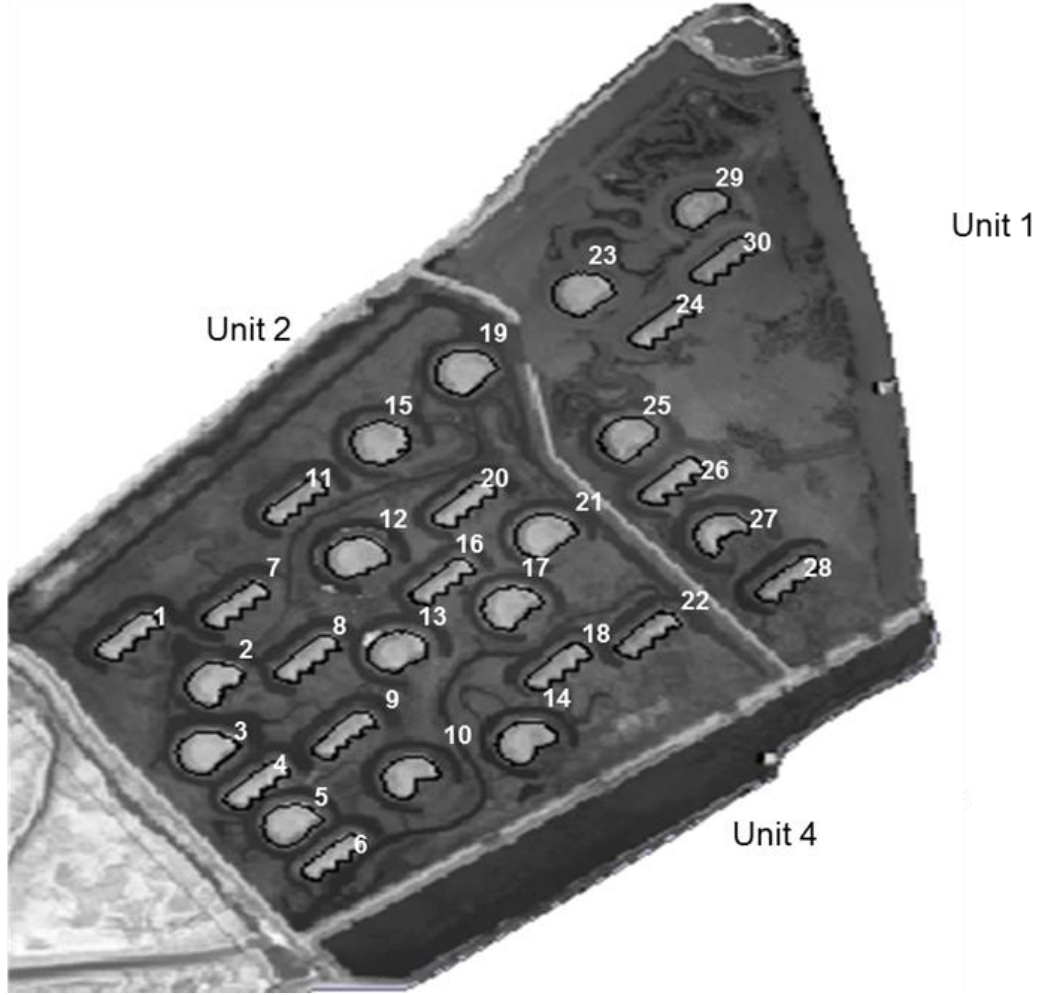

Figure 5. Mean bird abundance on islands. Panel a is the mean bird abundance at high tide across all islands. The error bars are $95 \%$ confidence intervals. Panel $b$ is an overview of the numbering of islands. 
Table 3. MANOVA results ( $d f=29,1650)$ : analysis of guild relative abundance variance among islands. Asterisks indicate a significant $p$-value. Dashes indicate that there was not enough data to complete the test.

\begin{tabular}{lcccc}
\hline & \multicolumn{2}{c}{ Low Tide } & \multicolumn{2}{c}{ High Tide } \\
Guild & $\mathrm{F}$ & $\mathrm{p}$-value & $\mathrm{F}$ & $\mathrm{p}$-value \\
\hline Small Shorebird & 1.05437 & 0.387 & 2.77854 & $<0.001^{*}$ \\
Medium Shorebird & 1.50994 & $0.040^{*}$ & 1.09892 & 0.328 \\
Large Shorebird & 1.49101 & $0.045^{*}$ & 3.22181 & $<0.001^{*}$ \\
Recurve & 0.75657 & 0.821 & 1.57598 & $0.027^{*}$ \\
Plover & 1.30223 & 0.130 & 1.60352 & $0.022^{*}$ \\
Heron & 1.46069 & 0.540 & 1.24882 & 0.170 \\
Tern & - & - & 0.71514 & 0.867 \\
Turnstone & - & - & - & - \\
Yellowlegs & 0.88560 & 0.642 & 4.93994 & $<0.001^{*}$ \\
Dabbler & 3.40059 & $<0.001^{*}$ & 4.34528 & $<0.001^{*}$ \\
Diver & 14.32283 & 0.117 & 0.90769 & 0.608 \\
Piscivore & 1.54570 & $0.032^{*}$ & 1.72652 & $0.010^{*}$ \\
Grebe & 1.00000 & 0.466 & - & - \\
Gull & 1.52157 & $0.038^{*}$ & 1.71451 & $0.011^{*}$ \\
Goose & - & - & - & - \\
Passerine & - & - & 1.00000 & 0.466 \\
Raptor & 1.00000 & 0.466 & 0.94555 & 0.549 \\
\hline
\end{tabular}

Table 4. Binary Logistic Regression results $(\mathrm{df}=1)$ : analysis of the presence/absences of guilds by island shape and size. Asterisks indicate a significant $p$-value. Dashes indicate that there was not enough data to complete the test. Confidence intervals only calculated when results were significant.

\begin{tabular}{|c|c|c|c|c|c|c|c|c|c|c|c|c|}
\hline \multirow[b]{3}{*}{ Guild } & \multicolumn{6}{|c|}{ Low Tide } & \multicolumn{6}{|c|}{ High Tide } \\
\hline & \multicolumn{3}{|c|}{ Island Shape } & \multicolumn{3}{|c|}{ Island Size } & \multicolumn{3}{|c|}{ Island Shape } & \multicolumn{3}{|c|}{ Island Size } \\
\hline & Odds Ratio & 95\% C.I. & $\mathrm{p}$-value & Odds Ratio & 95\% C.I. & $\mathrm{p}$-value & Odds Ratio & 95\% C.I. & $\mathrm{p}$-value & Odds Ratio & 95\% C.I. & $\mathrm{p}$-value \\
\hline Small Shorebird & 0.734 & - & 0.686 & 1.001 & - & 0.405 & 0.536 & $0.303-0.945$ & $0.031^{*}$ & 1.000 & - & 0.998 \\
\hline Medium Shorebird & 4.098 & - & 0.370 & 1.003 & - & 0.172 & 0.377 & - & 0.143 & 0.998 & - & 0.155 \\
\hline Large Shorebird & 0.373 & - & 0.197 & 1.000 & - & 0.799 & 2.548 & - & 0.143 & 1.002 & $1.000-1.004$ & $0.036^{*}$ \\
\hline Recurve & 2.172 & - & 0.483 & 1.002 & - & 0.371 & 3.510 & - & 0.205 & 1.002 & - & 0.132 \\
\hline Plover & 0.813 & - & 0.858 & 1.001 & - & 0.699 & 0.274 & & 0.051 & 0.999 & - & 0.292 \\
\hline Heron & 0.931 & - & 0.878 & 0.999 & - & 0.394 & 2.682 & $1.153-6.240$ & $0.022^{\star}$ & 1.001 & - & 0.181 \\
\hline Tern & - & - & - & - & - & - & 1.415 & - & 0.766 & 1.002 & - & 0.340 \\
\hline Turnstone & - & - & - & & - & - & - & - & - & - & - & - \\
\hline Yellow legs & 0.662 & - & 0.638 & 0.999 & - & 0.517 & 0.708 & - & 0.498 & 0.999 & - & 0.243 \\
\hline Dabbler & 0.731 & - & 0.207 & 0.999 & $0.998-1.000$ & $0.004^{*}$ & 0.827 & - & 0.417 & 0.999 & $0.998-1.000$ & $0.030^{*}$ \\
\hline Diver & 1.905 & - & 0.542 & 1.000 & - & 0.774 & 0.638 & - & 0.606 & 0.998 & - & 0.159 \\
\hline Piscivore & 10.691 & - & 0.055 & 1.003 & - & 0.145 & 3.119 & - & 0.095 & 1.002 & - & 0.149 \\
\hline Grebe & - & - & - & - & - & - & - & - & - & - & - & - \\
\hline Gull & 2.751 & - & 0.540 & 1.002 & $1.000-1.003$ & $0.030^{*}$ & 3.222 & $1.325-7.839$ & $0.010^{\star}$ & 1.002 & $1.001-1.003$ & $0.007^{\star}$ \\
\hline Goose & - & - & - & - & - & - & - & - & - & - & - & - \\
\hline Passerine & - & - & - & - & - & - & 0.000 & - & 0.985 & 0.936 & - & 0.984 \\
\hline Raptor & 0.000 & - & 0.958 & 0.678 & - & 0.932 & 0.209 & - & 0.426 & 0.998 & - & 0.598 \\
\hline
\end{tabular}




\subsection{Relative guild abundances predicted by island shape, size, slope, perimeter and distance to mudflat.}

Linear mixed models indicated that relative abundances of small sandpipers were better predicted by a model including shape with greater abundances on crescent-shaped islands at low $\left(\mathrm{t}_{6145}=-3.005, p=0.003\right)$ and high tide $\left(\mathrm{t}_{28}=-2.183\right.$, $p=0.038$ ). All random effects tested (mean slope of island, island perimeter, distance to mudflat or island area) failed to improve the models' predictions of the relative abundance of any guilds.

\section{Discussion}

Waterbirds, especially shorebirds, use tidal flats for roosting and foraging habitat at low tide when the habitat is exposed and use alternate roosting and foraging habitats only at high tide (Burger et al., 1977; Dias et al., 2006; Long \& Ralph, 2001; Warnock \& Takekawa, 1995). Similarly, I observed much higher abundances of waterbirds using the pond and islands at high tide. The cause of the $73.74 \%$ increase in waterbird abundance during the second year of observation is unclear. Possible explanations include differences in weather, benthic invertebrates, or pond water level. The San Francisco Bay is an important stop-over site on the Pacific Flyway as large numbers of birds migrate southward during the fall and northward during the spring (Page et al., 1999; Warnock et al., 2004). The lower number of birds using the pond in the winter and higher number of birds in the fall and the spring reflect bay-wide migratory patterns (Page et al., 1999; Wilson, 1994). 
These migration patterns, along with different foraging preferences, may have accounted for some of the changes in seasonal use among islands at high and low tide. I observed that islands were most heavily used during the spring at high tide. Small sandpipers accounted for most of this usage. These birds have a more diffuse fall migration ( July - October), whereas their spring migration is more concentrated when higher abundances of sandpipers are present (Wilson, 1994). This pattern was not observed at low tide, since sandpipers fly out to the mudflat for foraging, unlike the dabblers which drive the low tide island use patterns. Dabblers are not considered mudflat foragers; they usually forage in the water of impoundments in the estuary. Due to this difference in foraging locations, the dabblers were able to spend the whole tide cycle in the pond by roosting on the islands. Dabblers, unlike sandpipers, migrate in early spring (February -March) which explains their higher usage of islands in the fall and the winter during low tide (Austin \& Miller, 1995; Dubowy, 1996). The western sandpiper is one of the most common species of shorebirds found in the region (Page et al., 1999), so it was reasonable to see that they were the most common species observed in the pond. Use of roost sites can be inconsistent, variable, and dynamic with a few roost sites being primary and many others being used infrequently (Conklin et al., 2008; Conklin \& Colwell, 2007). This was clearly shown in the patterns of the monthly island abundance maps (Figure 5). Islands 24 and 25 may have been the primary roost locations with the other 28 islands being auxiliary roost sites. Other studies have indicated that proximity to foraging areas (in my study, proximity to mudflats for 
shorebirds) has influenced the use of roosts (Conklin et al., 2008; Dias et al., 2006; Furness, 1973; Warnock \& Takekawa, 1996). However, my models did not show the predictive value of distance to mudflat to guild presence or abundance.

At low tide, the relative abundances of only a few guilds differed among islands, and those guilds such as dabblers, piscivores, and gulls were not typically mudflat foragers and therefore not tidally dependent. Other guilds were not present on the pond at low tide while on the mudflat foraging, thus they were not counted at low tide. At high tide, relative abundance of more guilds, including small shorebirds, differed among islands indicating a preference.

I had expected that small shorebirds would prefer the linear islands due to the larger perimeter-to-area ratio, since shorebirds tend to prefer to roost very near to the water. However, this was not the case. When small shorebirds were present on the pond, regardless of tide, they were more likely to be found on crescent islands. The reason for this preference is not obvious. A few possible explanations could be that the crescent islands provided better protection from the wind, since high winds can cause birds to abandon roost locations (Burton et al., 1996). Alternatively, these islands may provide a larger area for a flock to congregate, whereas the multiple smaller areas of the linear island's saw-tooth edge do not. Herons may have been present more often on linear islands because the smaller edge areas provide multiple shallow sites for stalking fish.

None of the other guilds seemed to respond to island slope, perimeter, shape, size, or distance to mudflat. Other studies have suggested distance to mudflat (i.e. 
distance to forage) as an essential and defining roost characteristic (Dias et al., 2006; Rogers et al., 2006a; 2006b). However, this was not a significant factor in my results. Conklin et al. (2008) reported diurnal and nocturnal roost sites were not significantly related to distance to forage (although a relationship was observed in diurnal locations). It may be that the SF2 islands provide both diurnal and nocturnal roosts. Another factor may have been that all islands at SF2 were within $1000 \mathrm{~m}$ of a foraging location. The variation of islands within this limited distance from mudflats may not be enough to produce the effects of distance. Rogers et al. (2006a,b) showed that heat stress and energy expenditure influenced roost site selection; the relative closeness of all SF2 islands to mudflat may not result in stress or energy differences.

Other researchers found that island size was an important characteristic in nest site selection for both terns and herons (Eason et al., 2012; Erwin et al., 1995). Burton et al. (1996) suggested that various wader species prefer different island slopes, although I did not see that preference in the guilds studied at SF2.

This study at SF2 found that the waterbirds using newly-created islands for roosting were most influenced by island size and shape. Overall, the islands were not heavily used when compared with the overall pond. I was able to determine that a few foraging guilds had island preferences by shape and size, but, these preferences were not uniform and varied by guild.

As the restoration progresses and up to $90 \%$ of the ponds are converted to tidal marsh, roost sites will become less numerous and possibly more limiting. Thus, 
roost sites at SF2 may become much more important as the restoration proceeds. If constructed islands do not provide adequate roost sites, the overall result of conversion may result in a decline in the total abundance of waterbirds in the region.

Restoration project managers should not expect newly created islands to function as roost or foraging habitat for non-breeding waterbirds. However, if islands are built, the shape and area of the islands as well as the target guild should be carefully considered in light of the results from the SF2 experiment. Future studies should include an examination of the locations of nocturnal waterbird roosts and a determination of whether the current numbers of roosts are a limiting factor for waterbirds in the estuary. 


\section{References}

Ackerman, J. T., Bluso-Demers, J. D., \& Takekawa, J. Y. (2009). Postfledging Forster's Tern Movements, Habitat Selection, and Colony Attendance in San Francisco Bay. Condor, 111:100-110. doi:10.1525/cond.2009.080054

Altmann, J. (1974). Observational Study of Behavior: Sampling Methods. Behaviour, 49, 227-267.

Athearn, N. D., Takekawa, J. Y., Bluso-Demers, J. D., Shinn, J. M., Brand, L. A., Robinson-Nilsen, C. W., \& Strong, C. M. (2012). Variability in habitat value of commercial salt production ponds: implications for waterbird management and tidal marsh restoration planning. Hydrobiologia, 697, 139-155. doi:10.1007/s10750-012-1177-y

Austin, J,E, \& Miller, M.R. (1995). Northern Pintail (Anas acuta). In The Birds of North America Online. Retrieved from http://bna.birds.cornell.edu.oca.ucsc.edu/bna/species/163doi:10.2173/bna.16 $\underline{3}$

Barbier, E. B. (2011). Wetlands as natural assets. Hydrological Sciences JournalJournal Des Sciences Hydrologiques, 56, 1360-1373. doi:10.1080/02626667.2011.629787

Brand, L. A., L. M. Smith, J. Y. Takekawa, N. D. Athearn, K. Taylor, G. G. Shellenbarger, D. H. Schoellhamer, and R. Spenst. 2012. Trajectory of early tidal marsh restoration: elevation, sedimentation and colonization of breached salt ponds in the northern San Francisco Bay. Ecological Engineering, 42, 1929.

Burger, J., \& Lesser, F. (1978). Selection of Colony Sites and Nest Sites by Common Terns Sterna-Hirundo. Ibis, 120, 433-449. doi:10.1111/j.1474919X.1978.tb06810.x

Burgess, N., \& Hirons, G. (1992). Creation and Management of Artificial Nesting Sites for Wetland Birds. Journal of Environmental Management, 34, 285-295. doi:10.1016/S0301-4797(11)80004-6

Burton, N. H. K., Evans, P. R., \& Robinson, M. A. (1996). Effects on shorebird numbers of disturbance, the loss of a roost site and its replacement by an artificial island at Hartlepool, Cleveland. Biological Conservation, 77, 193201. 
Conklin, J. R., \& Colwell, M. A. (2007). Diurnal and nocturnal roost site fidelity of Dunlin (Calidris alpina pacifica) at Humboldt Bay, California. Auk, 124, 677689.

Conklin, J. R., Colwell, M. A., \& Fox-Fernandez, N. W. (2008). High variation in roost use by Dunlin wintering in California: Implications for habitat limitation. Bird Conservation International, 18, 275-291.

Dias, M. P. (2009). Use of Salt Ponds by Wintering Shorebirds throughout the Tidal Cycle. Waterbirds, 32, 531-537.

Dias, M. P., Granadeiro, J. P., Lecoq, M., Santos, C. D., \& Palmeirim, J. M. (2006). Distance to high-tide roosts constrains the use of foraging areas by dunlins: Implications for the management of estuarine wetlands. Biological Conservation, 131, 446-452.

Dubowy, P.J. (1996). Northern Shoveler (Anas clypeata). In The Birds of North America Online. Retrieved from http://bna.birds.cornell.edu.oca.ucsc.edu/bna/species/217doi:10.2173/bna.21 $\underline{7}$

Dunk, J.R. (1995). White-tailed Kite (Elanus leucurus). In The Birds of North America Online. Retrieved from http://bna.birds.cornell.edu.oca.ucsc.edu/bna/species/178doi:10.2173/bna.17 $\underline{8}$

Eason, P., Rabea, B., \& Attum, O. (2012). Island shape, size, and isolation affect nest-site selection by Little Terns. Journal of Field Ornithology, 83, 372-380. doi:10.1111/j.1557-9263.2012.00387.x

EDAW, Phillip Williams \& Associates, Ltd., H.T. Harvey \& Associates, Brown \& Caldwell. (2007). South Bay Salt Pond Restoration Project, Final Environmental Impact Statement/Report. San Francisco, CA: EDAW.

Erwin, R. M., Allen, D. H., \& Jenkins, D. (2003). Created versus Natural Coastal Islands: Atlantic Waterbird Populations, Habitat Choices, and Management Implications. Estuaries, 26, 949-955. doi:10.2307/1353517

Furness, R. W. (1973). Roost Selection By Waders. Scottish Birds, 7, 281-287.

Giroux, J. (1981). Interspecific Nest Parasitism by Redheads on Islands in Southeastern Alberta. Canadian Journal of Zoology-Revue Canadienne De Zoologie, 59, 2053-2057. 
Goals Project. (1999). Baylands ecosystem habitat goals. A report of habitat recommendations. Prepared by the San Francisco Bay Area Wetlands Ecosystem Goals Project. First Reprint. USEPA, San Francisco and San Francisco Bay Regional Water Quality Control Board, Oakland, CA, U.S.A.

Goals Project. (2000). Baylands Ecosystem Species and Community Profiles: life histories and environmental requirements of key plants, fish and wildlife. Prepared by the San Francisco Bay Area Wetlands Ecosystem Goals Project. P.R. Olofson, editor. San Francisco Bay Regional Water Quality Control Board, Oakland, CA, U.S.A.

Goss-Custard, J. D., Triplet, P., Sueur, F., \& West, A. D. (2006). Critical thresholds of disturbance by people and raptors in foraging wading birds. Biological Conservation, 127, 88-97.

H.T. Harvey \& Associates. (2005). Biology and Habitats Existing Conditions Report (1st ed.). California: H.T. Harvey \& Associates, Philip Williams \& Associates, Ltd., EDAW, and Brown \& Caldwell.

Helmers, D. L. (1992). Shorebird Management Manual. Western Hemisphere Shorebird Reserve Network.

Junk, W. J., An, S., Finlayson, C. M., Gopal, B., Kvet, J., Mitchell, S. A., Robarts, R. D. (2013). Current state of knowledge regarding the world's wetlands and their future under global climate change: a synthesis. Aquatic Sciences, 75, 151-167. doi:10.1007/s00027-012-0278-z

Kay, June (2002, December 17). \$100 million salt-pond deal sealed with Cargill. San Francisco Chronicle. Retrieved from http://www.sfgate.com/cgibin/article.cgi?f=/c/a/2002/12/17/BA66709.DTL

Long, L. L., \& Ralph, C. J. (2001). Dynamics of habitat use by shorebirds in estuarine and agricultural habitats in northwestern California. Wilson Bulletin, 113, 41-52. doi:10.1676/0043-5643(2001)113[0041:DOHUBS]2.0.CO;2

Maggiulli, N. M., \& Dugger, B. D. (2011). Factors Associated with Dusky Canada Goose (Branta Canadensis occidentalis) Nesting and Nest Success on Artificial Nest Islands of the Western Copper River Delta. Waterbirds, 34, 269-279.

Masero, J. A., \& Perez-Hurtado, A. (2001). Importance of the supratidal habitats for maintaining overwintering shorebird populations: How Redshanks use tidal mudflats and adjacent saltworks in Southern Europe. Condor, 103, 21-30. 
Okamoto, A. R., \& Wong, K. M. (2011). Natural History of San Francisco Bay. Berkeley and Los Angeles, CA: University of California Press.

Page, G. W., Stenzel, L. E., \& Kjelmyr, J. E. (1999). Overview of shorebird abundance and distribution in wetlands of the Pacific Coast of the contiguous United States. Condor, 101, 461-471. doi:10.2307/1370176

Parnell, J. F., Needham, R. N., Soots, R. F., Fussel, J. O., Dumond, D. M., McCrimmon, D. A.,Shields, M. A. (1986). Use of Dredged-Material Deposition Sites by Birds in Coastal North Carolina, USA. Colonial Waterbirds, 9, 210217.

Peters, K. A., \& Otis, D. L. (2007). Shorebird roost-site selection at two temporal scales: is human disturbance a factor? Journal of Applied Ecology, 44, 196209.

RAMSAR. Retrieved from http://www.ramsar.org/cda/en/ramsarhome/main/ramsar/1 40000

Rehfisch, M. M., Insley, H., \& Swann, B. (2003). Fidelity of overwintering shorebirds to roosts on the Moray Basin, Scotland: Implications for predicting impacts of habitat loss. Ardea, 91, 53-70.

Rogers, D. I. (2003). High-tide roost choice by coastal waders. Wader Study Group Bull., 100, 73-79.

Rogers, D. I., Battley, P. F., Piersma, T., Van Gils, J. A., \& Rogers, K. G. (2006a). High-tide habitat choice: insights from modelling roost selection by shorebirds around a tropical bay. Animal Behaviour, 72, 563-575. doi:10.1016/j.anbehav.2005.10.029

Rogers, D. I., Piersma, T., \& Hassell, C. J. (2006b). Roost availability may constrain shorebird distribution: Exploring the energetic costs of roosting and disturbance around a tropical bay. Biological Conservation, 133, 225-235. doi:10.1016/j.biocon.2006.06.007

Rosa, S., Encarnacao, A. L., Granadeiro, J. P., \& Palmeirim, J. M. (2006). High water roost selection by waders: maximizing feeding opportunities or avoiding predation? Ibis, 148, 88-97.

San Francisco Estuary Partnership. (2011). The State of San Francisco Bay 2011. Oakland, CA: JT Litho. 
Shaffer, T. L., Dahl, A. L., Reynolds, R. E., Baer, K. L., Johnson, M. A., \& Sargeant, G. A. (2006). Determinants of mallard and gadwall nesting on constructed islands in North Dakota. Journal of Wildlife Management, 70, 129-137. doi:10.2193/0022-541X(2006)70[129:DOMAGN]2.0.CO;2

Sibley, D. A. (2003). The Sibley Field Guide to Birds of Western North America. New York: Chanticleer Press.

Sitters, H. P., Gonzalez, P. M., Piersma, T., Baker, A. J., \& Price, D. J. (2001). Day and night feeding habitat of Red Knots in Patagonia: Profitability versus safety? Journal of Field Ornithology, 72, 86-95.

Sripanomyom, S., Round, P. D., Savini, T., Trisurat, Y., \& Gale, G. A. (2011). Traditional salt-pans hold major concentrations of overwintering shorebirds in Southeast Asia. Biological Conservation, 144, 526-537.

Takekawa, J. Y., Lu, C. T., \& Pratt, R. T. (2001). Avian communities in baylands and artificial salt evaporation ponds of the San Francisco Bay estuary. Hydrobiologia, 466, 317-328. doi:10.1023/A:1014546524957

Velasquez, C. (1992). Managing Artificial Saltpans as a Waterbird Habitat - Species Responses to Water Level Manipulation. Colonial Waterbirds, 15, 43-55.

Viani, L.A (Ed). (2006) State of the San Francisco Bay-Delta Estuary 2006. Science and Stewardship. Oakland, CA: San Francisco Estuary Project and CALFED.

Warnock, N., Takekawa, J. Y., \& Bishop, M. A. (2004). Migration and stopover strategies of individual Dunlin along the Pacific coast of North America. Canadian Journal of Zoology, 82, 1687-1697. doi:10.1139/z04-154

Warnock, N., Page, G. W., Ruhlen, T. D., Nur, N., Takekawa, J. Y., \& Hanson, J. T. (2002). Management and conservation of San Francisco bay salt ponds: Effects of pond salinity, area, tide, and season on Pacific flyway waterbirds. Waterbirds, 25, 79-92.

Warnock, S. E., \& Takekawa, J. Y. (1995). Habitat preferences of wintering shorebirds in a temporally changing environment: Western sandpipers in the San Francisco Bay Estuary. Auk, 112, 920-930.

Warnock, S. E., \& Takekawa, J. Y. (1996). Wintering site fidelity and movement patterns of western sandpipers Calidris mauri in the San Francisco Bay estuary. Ibis, 138, 160-167.

WHSRN. Retrieved from http://www.whsrn.org/site-profile/san-francisco-bay 
Wilson, H.W. (1994). Western Sandpiper (Calidris mauri). In The Birds of North America Online. Retrieved from http://bna.birds.cornell.edu.oca.ucsc.edu/bna/species/090doi:10.2173/bna.90 